\title{
Phosphonoacetic Acid
}

National Cancer Institute

\section{Source}

National Cancer Institute. Phosphonoacetic Acid. NCI Thesaurus. Code C84056.

An antiviral agent with activity ag ainst herpes simplex viruses and other members of the herpes virus family. Phosphonoacetic acid inhibits viral DNA polymerase and inhibits the synthesis of viral DNA. 